\title{
Analysis of the Capital Structure and Banks Performance: Evidence from Pakistan
}

Muhammad Ramzan Mehar*

University of Sialkot, Pakistan

\begin{abstract}
The study is attempted to test the significance of the impact of capital structure on financial performance of banks listed on Pakistan Stock Exchange. Study is explanatory in nature and deductive approach was adopted. The study incorporated financial performance variables as dependent and capital structure "financial structure" as independent. The dependent variables are spread ratio, return on assets and earnings per share and independent variables are total debt to total equity, long-term debt to total equity and Short-term debt to total equity. Furthermore, the study incorporated data for five years from 2011 to 2017. The time secrecies data is used for analysis. For calculation E-views software is used, Regression analysis is used to finding out the relationship and impact of dependent and independent variables.
\end{abstract}

Keywords: Capital structure; Earnings per share; Return on assets; Spread ratio

\section{Introduction}

\section{Background of the study}

This paper examines the impact of capital structure on banks performance listed on Pakistan stock exchange. The study spread the empirical works on capital structure determinates of banks within country. The capital structure decision plays an important role in the performance of a firm. Capital structure concept is generally described the combination of debts and equity that makes the total capital of firm. The selection of capital components and use of these components play an important role during the determining of financial strategies. Capital structure is one of the most puzzling issues on corporate finance. There are two major problems due to which capital structure is considering an issue in organization. The financial-debt-to-assets and Issuing activities verses leverages changes.

A company's capital structure is one of the important choices. Capital structure implies game plan of capital from various sources, so the long haul stores required for the business are raised. Because of its critical in association we can picked the subject for look into think about, it can assume an essential part in association's execution, and it can give many advantages to better execution. Capital structure boosted the market estimation of a firm. in firm having an appropriately planned capital structure the totals vale of the claim and proprietorship enthusiasm of investor are augmented. It can likewise limit the 'firm cost of financing'. By deciding a legitimate blend of assets sources a firm can keep the general cost of funding to the least. It can expand the organization's market cost of offer by expanding profit per offer of the customary investor. (The examination consolidated money related execution factors as reliant and capital structure (budgetary structure) as autonomous. The reliant factors are Spread Ratio, Return on Assets, and Earning per Share. Autonomous factors are Total Debts to Total Equity, Long term obligation to Total Equity, Short term obligation to Total Equity.

Our motivation of this examination is to survey the different capital structure speculations that have been giving the firm capital structure choices. Beginning from the capital structure insignificance hypothesis of Modigliani and Miller. It has been put the speculations that can clarify the capital structure. There are three noteworthy hypotheses that have been clarifying the ideal market of capital structure identified with demonstrate. Initial one is "exchange off hypothesis", that clarify the firm has one ideal obligation proportion and firm exchange off the advantages, cost of obligation and value financing. Second is "Pecking request hypothesis" Myers that assistance to the firm after a financing order where limited the issues. Third hypothesis is as of late presented By Baker and Warbler that is showcase timing hypothesis which clarify the present capital structure.

The reason for this examination is to research the impacts of Macromonetary parameters on the capital structure of Pakistan Firms. As indicated by the best of our insight this is the primary investigation of its kind in Pakistan and it will be open new skylines of research around there at last helping experts. Pervious examines in this contact Pakistan have taken firm particular factors' just which this examination is considers full scale monetary factors other than organization particular factors'. Capital structure is adversely related with banks execution. The examination extraordinarily clarifies that in the looks into of capital structure the money related and non-budgetary segments are not joined because the relationship is opposite [1].

\section{Problem statement}

The problem which is concentrated by researcher in this particular study to known about the impact of capital structure on banks performance in banking sectors of Pakistan. Capital structure is the mix of long term liabilities and favored stock. Capital structure assumes a fundamental part in budgetary association's execution. There are sure focuses that are the critical of capital structure that give benefits, yet there are additionally some negative focuses that are the issues of capital structure. Firm has legitimately planned the capital structure that expanded the possession enthusiasm of investors. Capital structure limits the organization's market cost of offers by expanding the procuring per offers of conventional investors. It can gives an advantage to expanding the nation rate of venture by expanding the company's opportunity to occupied with future-riches making

*Corresponding author: Muhammad Ramzan Mehar, Lecturer, University of Sialkot, Pakistan, Tel: +923076609503; E-mail: Ramzan_mehar@hotmail.com

Received June 14, 2018; Accepted June 22, 2018; Published June 28, 2018

Citation: Mehar MR (2018) Analysis of the Capital Structure and Banks Performance: Evidence from Pakistan. J Bus Fin Aff 7: 343. doi: 10.4172/21670234.1000343

Copyright: () 2018 Mehar MR. This is an open-access article distributed under the terms of the Creative Commons Attribution License, which permits unrestricted use, distribution, and reproduction in any medium, provided the original author and source are credited. 
speculation. The more liabilities an organization has, the more it needs to pay loan bosses for the utilization of those assets. In any case, the more liabilities go with gone up against, the more money it needs to create deals. There are two normal issues in capital structure explore. To start with, in spite of the fact that it is uncertain whether non-money related liabilities ought to be considered obligation, they ought to never be considered as value. However the normal money related obligation to-resource proportion measure of use submits this misstep. Second, value issuing movement ought not to be seen as counterparts to capital structure changes. So as for as we all know that banking business has more debt proportion in their capital structure. More debt depict more liabilities and it means that firm is more leveraged. It is need of the hours that to know about how more leveraged firms' financial position reacted that's whey proposed this study.

\section{Research objective}

The study has following specific objectives:

- To determine the impact of long-term-debt to equity ratio on the banking performance of private and public sectors banks.

- To analyze the impact of short-term-debt to equity ratio on the banking performance of private and public sectors banks.

- To verify the impact of capital structure on ratio on the banking performance of private and public sectors banks.

\section{Literature Review}

\section{The debt to equity ratio and bank performance}

Saeed et al. [2] and Zafar et al. [3] said in their study showed that the impact of capital structure on banking performance with in country and foreign country; Researcher include the Spread ratio, earning per share and Return on Assets as dependent variables, Total debt to total equity, Long term debt to Total equity, Short term debt to Total equity as independent variables. Researcher used the multiple reversion and regression model use to evaluate the relationship between capital structure and banking performance. Result of this study validated a positive relationship factor of capital structure and performance of banking industry. A positive image created in mind about bank if low risk involves the results of these consequences to improving the financial performance and good relationship between bank capital and bank performance. Other than that; Earning ratio, researcher measured the risk using to different tools. AS measured of risk the important role of 'behaviors financing'. If researcher takes high risk then result will be high return, if takes low risk the result will be low return.

Similar studies were conducted by various researchers with different topics, in this study discussed the factors affecting the Banks profitability in Pakistan by Gul and Irshad [4] and Ali [5] took external and internal factors that effects the profitability of banks. Researcher used the pooled ordinary least square (POLS) method to investigate the impact of assets, loan, equity, deposits growth on major profitability indicators. Return on assets (ROA), Return on equity (ROE), Return on capital employed (ROCE) and Net interest margins (NIM) are as dependent variables and internal and external factors as independent variables. The empirical results found that both internal and external factors have a strong influence on profitability. In 1997 examined the expansive business bank's productivity in the late 1980s by utilizing cross segment and pooled time arrangement cross area relapse. The examination test spreads the day and age of 1985 to 1990 of aggregate 201 banks. The consequences of the examination propose that Banks, poor execution are because of land advances while development and improvement. Advantages have a huge and positive effect on business banks benefits the increments and the determinants of business banks benefit by utilizing the weighted slightest square technique over the specimen time of 1988 to 1995 of aggregate 80 nations. The aftereffects of the examination propose that, ease financing lead to higher Gainfulness while expansion has positive effect on banks benefit since banks oversaw their cost well under high swelling.

Hypothesis - H1: The debt to equity ratio does has significant and positive impact on banking performance of private and public sectors banks.

\section{The long-term debt to equity ratio and bank performance}

This fascinating examination were directed by Zakori and Rouhi [6] and Siddik et al. [7] that demonstrated the Decisions on capital structure was one of the hardest and most difficult issues confronting the banks, yet in addition is the most Fundamental choice about proceeded with their survival. In this examination, analyst researched the connection between capital structures on the banks execution of the recorded banks in Tehran Stock Exchange for the 2008 to 2013 period for this reason, pros were used of three pointers of benefit for assets, return on esteem and pay per share as measures of bank execution. The Consequences of evaluating the model with settled effects methodology gathers that the capital structure decidedly influences pay per share and adversely influences return on assets, however no tremendous effect on return on esteem. Moreover, bank appraise has a basic and productive result on each one of the three execution criteria and besides asset improvement has a significant and Positive effect just on return on esteem. In this manner, banks and not-revenue driven affiliations like any affiliation are looking to accomplish benefit to guarantee their survival. To expand bank benefits are conceivable by expanding pay and lessening costs and to build the gainfulness of the bank ought to be to most extreme endeavors to get financing through the obtaining shabby of assets. Wellsprings of financing are crystalline in the capital structure that at last impact on the return on value. Because of the novel money related qualities of banks and the earth in that they work, there are strong purposes behind a different report on the determinants elements of banks capital structure.

Many researchers by Frederick [8] and Kristianti and Yovin [9] used the title the factors that affects the banks performance in domestic and foreign country, the elements are investigated in light of structure-lead execution (SCP) and Efficiency conjectures (ES). This is supplemented by Global preferred standpoint hypothesis together with Home field hypothesis. The examination investigations execution of all authorized local business banks spoke to by the normal execution. Utilizing Linear various relapse investigations over the period 20002011, the examination discovered that, administration proficiency; resource quality; premium wage; capital sufficiency and expansion are factors influencing execution of residential business banks in Uganda over the period 2000-2011. Strategy suggestions that rose up out of the investigation are as per the following; proficient administration; credit chance administration; capital sufficiency levels; broadening and business bank ventures. Money related arrangement directions and instruments ought not to authorize high liquidity and capital ampleness levels. Controls on non-premium pay exercises ought to be set up to orchestrate the effect of enhancement on every single business bank's execution and to maintain a strategic distance from abuse of bank clients.

Hypothesis - H2: The long-term-debt to equity ratio has significant and positive impact on banking performance of private and public sectors banks. 


\section{The short-term debt to equity ratio and banks performance}

These examinations were directed by to for the most part investigate the relationship of capital structure and its impact on organization's execution Test included 33 recorded associations from sustenance range of Pakistan. Commitment extents including commitment to esteem, here and presently commitment to signify assets and whole deal commitment to indicate assets have been used as consistent components while return on assets and pay per share have been used as go-between of execution. Assumptions of multi co linearity, hetero skeda sticity, contemporaneous association and auto relationship have been attempted and in light of the results PCSE close by Prais-Winsten backslide has been used. Eventual outcomes of backslide examination revealed negative association of capital structure extents with execution while among these, selective commitment to esteem extent has vital effect on association's execution. Negative association of capital structure extents incite the conclusion that sustenance portion isn't fittingly utilizing commitment in its capital structure and cash related examination need to find a perfect mix of commitment and incentive for extension of association's advantages. Results in like manner exhibit that at for the most part low level of utilization if the banks augment the measure of commitment in capital structure, it prompts augment the advantage adequacy and finally the bank's execution [10]

Hypotheses - H3: The short-term-debt to equity ratio has significant and positive impact on banking performance of private and public sectors banks.

H4: The capital structure has significant and positive impact on banking performance of private and public sectors banks.

\section{Research Design and Methodology}

In this research study, research design is quantitative nature that is particularized following head. The primary theme is to detect the econometric techniques and methodology.

\section{Time period}

The data for this study is the yearly ratio of different banks of Pakistan. In this research, researcher use regression model technique, 25 different banks included privet and public sectors are selected for analysis. In this study, researcher used five-year data from 2011 to 2015. The reasons for selecting this period are the researcher's wants to check the relationship of capital structure and banks performance.

\section{Nature and source of data}

To explore the association among different banks of Pakistan of this study quantitative and secondary data is used. The research is based on secondary data of 25 different banks including private and public sectors. The researcher used the yearly ratios of banks. Data is collected from official website of state bank for the period of 2011-2015.

\section{Unit of analysis}

A standout amongst the most vital thoughts in an examination venture is the unit of Rupees. The unit of Rupees is the real substance that you are breaking down in your examination. The accessible works gives a total clarification of variables disturbing Banks performance. In order to analyze the determinants of bank performance in Pakistan we, include six related variables, three as dependent variable such as Spread Ratio, ROA, and Earnings Per share. Three used as independent variables Total debt/Total equity, long term debt/total equity, Short term debt/total equity. To measure the effect of capital structure on banks performance annually data is used in the unit of Rupees.

\section{Methodology}

This region holds the basic methodologies and entire strategy to satisfy the target of investigation examine Time arrangement information is broke down by utilizing E-Views for count. The principal Descriptive Statistics strategy outlines factors both measurably and graphically. Data about the area (focus), spread (changeability), and circulation is given. The strategy gives a huge assortment of factual data about a solitary variable and furthermore computation is to quantify the normal outcome and standard deviation. The objective of a connection examination is to see whether two estimation factors co fluctuate, and to evaluate the quality of the connection between the factors, though relapse communicates the relationship as a condition. We can utilize the connection coefficient, for example, the Pearson Product Moment Correlation Coefficient, to test if there is a straight connection between the factors.

To evaluate the quality of the relationship, we can ascertain the connection coefficient. In relapse examination, the issue of intrigue is simply the idea of the connection between the reliant (reaction) and the (illustrative) free factor. The investigation comprises of picking and fitting a proper model, done by the technique for slightest squares, with a view to abusing the connection between the factors to help evaluate the normal reaction for a given estimation of the autonomous variable. Coefficient is a measure of relationship between two parallel factors. The measure was produced by AbuTawahina and Helles [11].

\section{Results and Interpretations}

\section{Regression}

Estimation of the reliant variable for a given estimation of the free factor (roof line as opposed to focal line) keeping in mind the end goal to distinguish what estimation of the autonomous variable is vital yet not adequate for a given estimation of the needy variable. Relapse examination is broadly utilized for expectation and gauging, where its utilization has considerable cover with the field of machine learning. Relapse examination is likewise used to comprehend which among the autonomous factors are identified with the needy variable, and to investigate the types of these connections. In confined conditions, relapse examination can be utilized to induce causal connections between the free and ward factors.

Hypothesis - H0: Independent variables have not positive and significant impact on dependent variables.

H1: Independent variables have positive and significant impact on dependent variables (Table 1).

Estimation Equation: Spread Ratio $=\mathrm{C}(1)+\mathrm{C}(2)^{\star}$ Short Debt $+C(3)^{\star}$ Total debt $+C(4)^{\star}$ Long Term debt

Substituted Coefficients: Spread Ratio $=0.565419143071$ $0.0342422074352^{\star}$ Short Debt $+0.0045825336341^{\star}$ Total Debt $0.00740323679862 *$ Long term.

The result of Table 1 shows that value of $\mathrm{R}$ square and adjusted $\mathrm{R}$ square's value being 0.592443 and -0.630228 respectively shows that most of variation in spread ratio is explained by` independent variable TD/TE,LTD/TE,STD/TE in this model. According to our particular study the value of $\mathrm{R}$ squares is 0.59 which is equal to $59 \%$ and this variance show the dependent variable and remaining percentage which is $41 \%$ show the other independent variable. In this study also explain the "Durban-Watson" this study also checks the autocorrelation test. Auto correlation is the assumption of regression analysis. The Durban 


\begin{tabular}{|c|c|c|c|}
\hline Variable & Coefficient & Std. Error & t-Statistic \\
\hline C & 0.565419 & 0.230143 & 2.456815 \\
\hline Short debt & -0.034242 & 0.032827 & -1.043097 \\
\hline Total Debt & 0.004583 & 0.022945 & 0.0461 \\
\hline Long term debt & -0.007403 & 0.018455 & -0.401157 \\
\hline R-squared & 0.592443 & \multicolumn{2}{|c|}{ Durbin-Watson stat } \\
\hline Probe(F-stat) & 0.007531 & F-statistic & 0.05745 \\
\hline
\end{tabular}

Dependent Variable: Spread Ratio

Table 1: Regression Analysis (OLS Method).

\begin{tabular}{|c|c|c|c|}
\hline Variable & Coefficient & Std. Error & Prob. \\
\hline C & 0.006186 & 0.002482 & 2.49232 \\
\hline Short debt & -0.000368 & 0.000199 & -1.846919 \\
\hline Total Debt & 0.000156 & 0.000354 & 0.0159 \\
\hline Long term debt & 0.000352 & 0.000247 & 0.741828 \\
\hline R-squared & 0.910597 & \multicolumn{2}{|c|}{ Durbin-Watson stat } \\
\hline Probe(F-stat) & 0.034951 & F-statistic & 0.0901 \\
\hline
\end{tabular}

Dependent Variable: Spread Ratio

Table 2: Regression Analysis (OLS Method).

\begin{tabular}{|c|c|c|c|c|}
\hline Variable & Coefficient & Std. Error & Prob. \\
\hline C & 6.760131 & 2.244042 & 0.204 \\
\hline Short debt & -0.135444 & 0.179945 & -0.01248 \\
\hline Total Debt & -0.543079 & 0.320089 & -1.696651 \\
\hline Long term debt & 0.075047 & 0.223727 & 0.335438 \\
\hline R-squared & 0.833473 & \multicolumn{2}{|c|}{ Durbin-Watson stat } \\
\hline Probe(F-stat) & 0.504776 & F-statistic \\
\hline
\end{tabular}

Method: Least Squares

Table 3: Dependent Variable: Earning Per Share.

Watson measurement is a test measurement used to distinguish the nearness of autocorrelation (a connection between values isolated from each other by a given time slack) in the residuals. The range of DurbanWatson is (1-4) if this range is less than 1.5 then the value is negative, if this range is more than 2.5 then the value is positive. And if this value is between the ranges of 1.5 to 2.5 then there is no any auto correlation between variables. In our analysis the value of Durbin - Watson is 1.702 that shows the no any auto correlation between the variables. As for value of $\mathrm{F}$. statistics probability shown as table if the value of $\mathrm{F}$. statistics is less than 0.05 then the model is goodness of fitness of model otherwise not significant. Our F. Statistics value is 0.04 this can show the goodness and fitness of model (Table 2).

Estimation equation: Return on assets $=\mathrm{C}(1)+\mathrm{C}(2)^{\star}$ Long term $\operatorname{debt}+\mathrm{C}(3)^{\star}$ Short debt $+\mathrm{C}(4)^{\star}$ Total debt

Substituted coefficients: Return on assets $=0.00618597182371$ $0.000367588260942^{\star}$ Long-term Debt $+0.000156421531955^{\star}$ Short term debt $+0.00035198147671^{\star}$ Total Debt.

The result of Table 3 shows that value of $\mathrm{R}$ square and adjusted $\mathrm{R}$ square's value being 0.910597 and 0.642390 respectively shows that most of variation in Returns on assets is explained by independent variable TD/TE,LTD/TE,STD/TE in this model. According to our particular study the value of $\mathrm{R}$ squares is 0.91 which is equal to $91 \%$ and this variance show the dependent variable and remaining percentage which is $11 \%$ show the other independent variable. In this study also explain the "Durban-Watson" this study also check the autocorrelation test. Auto correlation is the assumption of regression analysis. The Durban Watson measurement is a test measurement used to distinguish the nearness of autocorrelation (a connection between values isolated from each other by a given time slack) in the residuals. The range of
Durban- Watson is (1-4) if this range is less than 1.5 then the value is negative, if this range is more than 2.5 then the value is positive. And if this value is between the ranges of 1.5 to 2.5 then there is no any auto correlation between variables. In our analysis the value of Durbin Watson is 1.702 that shows the no any auto correlation between the variables. As for value of F. statistics probability shown as table if the value of F. statistics is less than 0.05 then the model is goodness of fitness of model otherwise not significant. Our F. Statistics value is 3.39 this cannot shows the goodness and fitness of model (Table 3).

Estimation equation: Earnings per Share $=\mathrm{C}(1)+\mathrm{C}(2)^{\star}$ Long Term Debt $+C(3)^{\star}$ Short debt $+C(4)^{\star}$ Total Debt.

Substituted coefficients: Earnings per Share $=6.7601313942$ $0.135444285558^{\star}$ Long-term Debt- $0.543078631234^{\star}$ Short Debt + $0.0750466772877^{\star}$ Total Debt.

The result of Table 3 shows that value of $\mathrm{R}$ square and adjusted $\mathrm{R}$ square's value being 0.9833483 and 0.9333891 respectively shows that most of variation in Earning per shares is explained by' independent variable TD/TE, LTD/TE, STD/TE in this model. According to our particular study the value of $\mathrm{R}$ squares is 0.93 which is equal to 93\% and this variance show the dependent variable and remaining percentage which is $7 \%$ show the other independent variable. In this study also explain the "Durban-Watson" this study also check the autocorrelation test. Auto correlation is the assumption of regression analysis. The Durban Watson measurement is a test measurement used to distinguish the nearness of autocorrelation (a connection between values isolated from each other by a given time slack) in the residuals. The range of Durban-Watson is (1-4) if this range is less than 1.5 then the value is negative, if this range is more than 2.5 then the value is positive. And if this value is between the ranges of 1.5 to 2.5 then there 
is no any auto correlation between variables. In our analysis the value of Durbin-Watson is 1.702 that shows the no any auto correlation between the variables. As for value of F. statistics probability shown as table if the value of F. statistics is less than 0.05 then the model is goodness of fitness of model otherwise not significant. Our F. Statistics value is 1.6 this cannot show the goodness and fitness of model [12].

\section{Conclusion}

The study is attempted to test the significance of impact of capital structure on banks performance in Pakistan. For this purpose 25 banks were selected randomly public and private sectors from all listed banks on Pakistan Stock Exchange. As indicated by the unmistakable outcomes the private segment banks are the preferable entertainers over people in general division banks. The measure reason is that the general population area banks confront part of snags in key control and arranging due degenerate administration and administration. The bar outlines of open part banks identified with execution portrayed constantly diminishing on yearly premise however in private segment banks' patterns are inverse. Study utilized two unique strategies for investigation where one was graphic and second was customary minimum square relapse. The examination utilized advance insightful relapse in which three synchronous conditions were utilized to test the effect of capital structure on banks execution. The fundamental gauge of the investigation is budgetary execution which was measured by three distinct factors (spread proportion, return on resources and profit per share). The estimator utilized for foreseeing the outcomes was capital structure which was likewise measured by three distinct techniques first by Ooi and facilitate by Amidu. All estimators anticipated the negative effect in relapse investigation of capital structure on banks budgetary execution. Every invalid theory couldn't be Acknowledged at level importance 0.01 along these lines it can be closed from the contemplated confirm that in saving money part of Pakistan the capital structure is contrarily related with banks budgetary execution. In keeping money area part of obligation is extensive in financing in light of the fact that the bank is the organization which produces credit cash. The measure segment of banks' accounting report is financed by stores of the clients, Therefore the advantages of ideal capital structure can't be profited by keeping money area in light of the fact that the there is no understanding of ideal level of capital structure in saving money segment. This paper will exceptionally enable the researcher's to assess their examination to work in better frame. Particularly in the investigation of capital structure the effect of capital structure is inverse on monetary execution in money related area and non-budgetary division. With the assistance of this work financial specialists can dissect changes in stock costs of banks because of progress in capital structure. There are numerous other execution pointers of managing an account division those can be utilized as a part of future investigations and test size can be expanded to build the dependability of results in future.

\section{References}

1. Abeywardhana DKY (2017) Capital structure theory: An overview. Accounting and Finance Research 6: 133.

2. Saeed MM, Gull AA, Rasheed MY (2014) Impact of Capital Structure on Banking Performance (A Case Study of Pakistan). Institute of Interdisciplinary Business Research 4: 393-403.

3. Zafar MR, Zeeshan F, Ahmed R (2016) Impact of Capital Structure on Banking Profitability. Impact of Capital Structure on Banking Profitability 6: 186-193.

4. Gul S, Irshad F (2011) Factors Affecting Bank profitability in Pakistan. Rom Econ J 14: 61-87.

5. Ali M (2015) Bank profitability and its determinants in Pakistan: A panel data analysis after financial crisis. MPRA, pp: 1-23.

6. Zakori S, Rouhi L (2015) The Impact of Capital Structure on Banks Performance: A Case Study of Iran. J Appl Environ Biol Sci 5: 112-119.

7. Siddik MNA, Kabiraj S, Joghee S (2017) Impacts of Capital Structure on Performance of Banks in a Developing Economy: Evidence from Bangladesh. Int J Financial Stud 5: 1-18.

8. Frederick NK (2015) Factors affecting the performance of banks in Uganda: A Case for Domestic Commercial Banks. International Review of Business Research Papers pp: 1-19.

9. Kristianti RA, Yovin (2013) Factors Affecting Bank Performance: Cases of Top 10 Biggest Government and Private Banks in Indonesia in 2004-2013. Rev Integr Bus Econ Res 5: 371.

10. Mujahid M, Zuberi MA, Rafiq MQ, Sameen SN, Shakoor MA (2014) Impact of Capital Structure on Banking Performance. Research Journal of Finance and Accounting 5: 99-104.

11. AbuTawahina MS, Helles SA (2015) Capital Structure and Firms Financia Performance: Evidence from Palestine. Islamic University, Gaza, pp: 2-96.

12. Brutlag JD (2007) The Development of Correlation and Association in Statistics. 